$\xi=-1$

\title{
A Survey of using Data Mining Techniques for Soil Fertility
}

\author{
Madhuri Kommineni ${ }^{1 *}$, Someswari Perla², Divya Bharathi Yedla ${ }^{3}$ \\ ${ }^{1}$ Asst.Professor, Department of CSE, KL E F \\ ${ }^{2,3}$ Asst.Professor, Department of CSE, G M R I T \\ *Email: madhuri.cbit@gmail.com
}

\begin{abstract}
Data Mining is a technique which focuses on large data sets to extract information for prediction and discovery of hidden patterns. Data Mining is applicable on various areas like healthcare, insurance, marketing, retail, communication, agriculture. Agriculture is the backbone of country's economy. It is the important source of livelihood. Agriculture mainly depends on climate, topography, soil, biology. Agricultural Mining is a technology which can bring knowledge to agriculture development. Data Mining in agriculture plays a role in weather forecasting, yield prediction, soil fertility, fertilizers usage, fruit grading, plant disease and weed detection. The current study presents the different data mining techniques and their role in context of soil fertility, nutrient analysis.
\end{abstract}

Keywords: Data Mining; K-Means; Soil Fertility; Soil Nutrient; SVM;

\section{Introduction}

Globally, day to day the need for food is escalating, therefore the agricultural scientists, farmers, government, and researchers are trying and using varied techniques in agriculture for improvement in production. As an impact, the information generated from the agricultural data is increasing day by day. Because the volume of information enlarged, it needs a spontaneous method for this information to be mined and analyzed once required. Data Mining techniques will be used for prediction the longer term trends of agricultural processes.

Data Mining techniques are of two types, one is descriptive which considers the existing data and another is predictive which depends on probability for future analysis. Data Mining process involves

a) Collect, clean and load the data into data warehouse system

b) Stores the data in multidimensional format

c) Provides information access to analysts and decision makers

d) Analyzation of data using different ap plications

e) Presents the data using different patterns

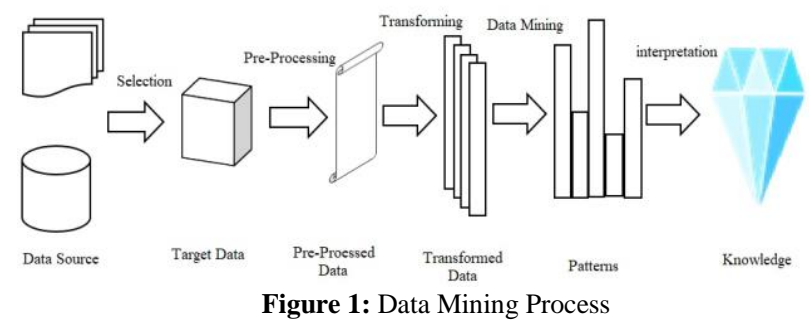

\section{Literature Survey}

Data Mining is applied to analyze large data sets and found useful patterns in the data. Data Mining is used in various fields to recognize patterns which are used in analyzation and prediction. Many studies describe how to analyze agricultural data especially soil information by using classification, regression, correlation, clustering and machine learning. The results of soil analysis on different data sets with a range of Data Mining techniques may useful to farmers to get right insight to perform their activities with less cost and to improve the crop yields, such as by measuring soil properties the farmers can decide what kind of crops to be adopted and use of fertilizers etc. The soil analysis may use in many dimensions such as to protect the environment, diagnosis of crop culture troubles, to identify nutrient deficiencies, energy conversation, and so on. In soil analysis, we can test different properties of soils like $\mathrm{pH}$, organic matter, ammonium $\mathrm{N}$, calcium carbonate equivalency, etc.

The most restraining component to agriculture productivity is soil fertility. Soil fertility is characterized as the state of a dirt that empowers it to give supplements in sufficient sums and inappropriate adjust for the development of indicated plants when other development factors, for example, light, water, temperature, and physical state of the soil, are good. Soils fluctuate in their ripeness, physical science, and mineralogy and therefore they have diverse levels of fertility. There are distinctive sorts of soils with shifting fertility status.

Guntur District, Andhra Pradesh soils are mainly divided into 4 types as follows:

1. Red Gravelly Soils: Like the black soil, red soils are maximum regur and unable to hold the water. Perfect use of fertilizers and irrigation procedures in the red soil gives a rich yield of rice, tobacco, wheat, oilseeds, and fruits.

2. Black Cotton Soils: The black soil is rich in chemical properties and very suitable for the growth of cotton, sorghum, wheat, linseed, groundnut, and gram. In horticulture crops Mango, Sapota, Guava, and Banana are main fruit crops and vegetables like Peas, Brinjal, Tomato, Green chili etc. are grown. In black soil, there should be proper drainage of water. There are mainly two problems in black soil i.e. waterlogging and soil salinity.

3. Sandy Alluvial Soils: Alluvial soils are general in nature and adaptable for farming. They are most appropriate to the water system and react well to channel and well/tube-well water system. 
These soils give a good yield of rice, sugarcane, cotton, jute, maize, tobacco, wheat, vegetables.

4. Saline Alkali Soils: These dirts are regularly fruitless. Notwithstanding, the administration of waste, great water system, and utilization of lime as well as gypsum joined with natura administration can make these dirts fit for the development of an assortment of yields. Antacid soils can develop wheat, grain, oat, sorghum, cotton, grapes and so on. Saline-soluble base soils can develop paddy, oat, and grain while saline soils can develop rice, sugarcane and castor.

The following shows soil nutrient information in Guntur district of Andhra Pradesh, India.

Table1: Soil Nutrient status in Guntur District

\begin{tabular}{|l|l|l|l|}
\hline \multicolumn{1}{|c|}{ Nutrient } & Low & Medium & High \\
\hline $\mathrm{pH}$ & $1 \%$ Acidic & $99 \%$ Neutral & $0 \%$ Alkaline \\
\hline $\begin{array}{l}\text { EC- Electrical } \\
\text { Conductivity }\end{array}$ & $90 \%$ Normal & $\begin{array}{l}6 \% \text { Slightly } \\
\text { Saline }\end{array}$ & $4 \%$ Saline \\
\hline $\begin{array}{l}\text { OC- Organic } \\
\text { Corban }\end{array}$ & $100 \%$ & $0 \%$ & $0 \%$ \\
\hline N- Nitrogen & $100 \%$ & $0 \%$ & $0 \%$ \\
\hline P- Phosphorous & $0 \%$ & $0 \%$ & $100 \%$ \\
\hline K- Potassium & $0 \%$ & $3 \%$ & $97 \%$ \\
\hline S- Sulphur & $1 \%$ & $5 \%$ & $94 \%$ \\
\hline Zn- Zinc & $1 \%$ Deficient & & $\begin{array}{l}99 \% \\
\text { Sufficient }\end{array}$ \\
\hline Fe- Iron & $0 \%$ Deficient & & $\begin{array}{l}100 \% \\
\text { Sufficient }\end{array}$ \\
\hline Cu- Copper & $0 \%$ Deficient & & $\begin{array}{l}100 \% \\
\text { Sufficient }\end{array}$ \\
\hline Mn- Manganese & $100 \%$ Deficient & & $0 \%$ Sufficient \\
\hline B-Boron & $0 \%$ Deficient & & $\begin{array}{l}100 \% \\
\text { Sufficient }\end{array}$ \\
\hline
\end{tabular}

\section{Usage of Data Mining techniques in various fields of agriculture}

Data Mining has wide scope within the field of agriculture, particularly on soils to derive information. Numerous techniques of mining and machine learning square measure probably utilized in agriculture for estimation and prediction of farming problems. The fuzzy algorithms square measure applied to managing crops, K-means algorithmic rule to classify soils, SVM technique applied to prediction of yields, ANN techniques square measure counseled to search outcrop diseases, ICA-Integrated element Analysis plays important role in meteorology. Data processing regression models used to estimate soil-water-retention, and proportion of organic matter. The scope of the mining and machine learning is huge; the subsequent areas have sure scope on soil analysis.

i. Predicting trends and behavior of soils betting on ingredients and climate conditions.

ii. Discovery of soil patterns that are unknown.

iii. Decision trees for crop and soil management.

iv. Artificial Neural Networks for sensing the soils for the adoption of crops.

v. Genetic algorithms used for soil allocation ways.

vi. Nearest neighbor ways for soils classification.

vii. Rule primarily based induction for yield prediction.

Table2: Study of DM Methods that are used in Agriculture by various authors

\begin{tabular}{|c|c|c|c|c|}
\hline $\begin{array}{l}\text { S. } \\
\text { N } \\
\text { o }\end{array}$ & Title of Work & Outcome & $\begin{array}{c}\text { DM } \\
\text { Techniques } \\
\text { Used }\end{array}$ & $\begin{array}{c}\text { Name of } \\
\text { Biograp } \\
\text { her }\end{array}$ \\
\hline 1 & $\begin{array}{l}\text { Data Mining } \\
\text { Techniques in } \\
\text { Agriculture } \\
\text { Prediction of Soil } \\
\text { Fertility }\end{array}$ & $\begin{array}{l}\text { Prediction of } \\
\text { Soil Fertility }\end{array}$ & $\begin{array}{c}\text { Naïve } \\
\text { Bayes, } \\
\text { J48(C4.5), } \\
\text { JRip }\end{array}$ & $\begin{array}{c}\mathrm{K} \\
\text { Samund } \\
\text { eeswari } \\
\text { \& Dr K } \\
\text { Srinivas } \\
\text { an }\end{array}$ \\
\hline 2 & $\begin{array}{c}\text { An Analysis of } \\
\text { Agricultural Soils }\end{array}$ & $\begin{array}{c}\text { Soil } \\
\text { Classification }\end{array}$ & $\begin{array}{l}\text { K-Means, } \\
\text { SVM, ANN }\end{array}$ & $\begin{array}{c}\text { Ramesh } \\
\text { Babu }\end{array}$ \\
\hline
\end{tabular}

\begin{tabular}{|c|c|c|c|c|}
\hline & $\begin{array}{c}\text { by using Data } \\
\text { Mining Techniques }\end{array}$ & $\begin{array}{l}\text { using GPS } \\
\text { based } \\
\text { Technology }\end{array}$ & & $\begin{array}{l}\text { Palepu, } \\
\text { Rajesh } \\
\text { Reddy } \\
\text { Muley }\end{array}$ \\
\hline 3 & $\begin{array}{c}\text { Soil Data Analysis } \\
\text { Using } \\
\text { Classification } \\
\text { Techniques }\end{array}$ & $\begin{array}{l}\text { Classification } \\
\text { of soil and } \\
\text { Prediction of } \\
\text { untested } \\
\text { attributes }\end{array}$ & $\begin{array}{c}\text { Least } \\
\text { Median } \\
\text { Square } \\
\text { Regression, } \\
\text { Classical } \\
\text { regression } \\
\text { Techniques, } \\
\text { J48 } \\
\end{array}$ & $\begin{array}{c}\text { Jay } \\
\text { Gholap, } \\
\text { Shailesh } \\
\text { Gagrade }\end{array}$ \\
\hline 4 & $\begin{array}{c}\text { Data Mining } \\
\text { Technique to } \\
\text { Analyze Soil } \\
\text { Nutrients based on } \\
\text { Hybrid } \\
\text { Classification }\end{array}$ & $\begin{array}{c}\text { Analysis of } \\
\text { Soil Nutrients }\end{array}$ & $\begin{array}{c}\text { Naïve } \\
\text { Bayes, } \\
\text { Decision } \\
\text { Tree and } \\
\text { Hybrid } \\
\text { Classificatio } \\
\text { n } \\
\end{array}$ & $\begin{array}{c}\text { E. } \\
\text { Manjula } \\
\text { and S. } \\
\text { Djodilta } \\
\text { choumy }\end{array}$ \\
\hline 5 & $\begin{array}{l}\text { A Study of Data } \\
\text { Mining Tools and } \\
\text { Techniques to } \\
\text { Agriculture with } \\
\text { Applications }\end{array}$ & $\begin{array}{l}\text { Comparative } \\
\text { Study of Data } \\
\text { Mining } \\
\text { Techniques in } \\
\text { various fields } \\
\text { of Agriculture } \\
\end{array}$ & $\begin{array}{l}\text { SVM, ANN, } \\
\text { K-Means, } \\
\text { KNN, } \\
\text { Bayesian } \\
\text { Network, bi- } \\
\text { clustering } \\
\end{array}$ & $\begin{array}{c}\text { Noor } \\
\text { Ayesha }\end{array}$ \\
\hline 6 & $\begin{array}{l}\text { Application of Data } \\
\text { Mining } \\
\text { Classification } \\
\text { Techniques on Soil } \\
\text { Data Using R }\end{array}$ & $\begin{array}{c}\text { Comparative } \\
\text { Study of Soil } \\
\text { Data }\end{array}$ & ANN,SVM & $\begin{array}{c}\text { Nikhita } \\
\text { Awasthi, } \\
\text { Abhay } \\
\text { Bansal }\end{array}$ \\
\hline
\end{tabular}

\section{Conclusion}

Agriculture is the utmost important area especially in the mellowing country like India. Use of information technology in agriculture can change the scenario of decision making and framers can yield in a better way. For decision making on overall issues related to agriculture field; data mining plays a vital role. The survey discussed the role of data mining in terms of agriculture field. We have also discussed various types of soils, several data mining techniques in agriculture and soil containment.

\section{References}

[1] OliviuMatei et al, "A DataMining System for Real Time Soil Moisture Prediction", ScienceDirect,2017

[2] Jharna Majumdar, Sneha Naraseeyappa, Shilpa Ankalaki, "Analysis of agriculture data using data mining techniques : application of big data", Springer,2017

[3] K. Samundeeswari, Dr.K.Srinivasan, "DataMining Techniques in Agriculture Prediction of Soil Fertility",IJSER,2017

[4] SupriyaDM, "Analysis of Soil behavior and Prediction of Crop Yield using Data Mining Approach”, IJIRCCE.

[5] R.Sukanya, K.Prabha, "Comparative analysis for prediction of rainfall using data mining techniques with artificial neural network", IJCSE, 2017.

[6] P.RamesgBabu, Rajesh Reddy M, "An Analysis of agricultural soils by using data mininig techniques", IJESC, 2017

[7] BVRamaKrishna, Dr.B,Satyanarayana, "Agriculture Soil Test Report Data Mining for Cultivation Advisory", IJCA,2016

[8] D.Sabreeswaran, A.Edwin Robert, "A survey on data mining techniques in agriculture", IJID, 2016. 